\title{
BIOCHEMICAL PROFILE OF WILD-CAPTURED INDIAN FLYING FOX (Pteropus giganteus) IN BANGLADESH
}

\author{
M. B. Hossain ${ }^{1 *}$, M. N. Islam², A. H. Shaikat ${ }^{1}$, M. G. Yasin ${ }^{3}$, M. M. Hassan ${ }^{1}$, S. K. M. A. Islam ${ }^{1}$, A. \\ Rahman $^{4}$, M. A. Mamun ${ }^{1}$, S. A. Khan ${ }^{1}$. \\ ${ }^{1}$ Department of Physiology, Biochemistry and Pharmacology, Chittagong Veterinary and Animal Sciences \\ University Chittagong-4225, Bangladesh \\ ${ }^{2}$ Intern Student, Chittagong Veterinary and Animal Sciences University, Chittagong-4225, Bangladesh \\ ${ }^{3}$ Department of Parasitology, Bangladesh Agricultural University, Mymensingh-2202, Bangladesh \\ ${ }^{4}$ Department of Agricultural Economics \& Social Sciences, Chittagong Veterinary and Animal Sciences \\ University, Chittagong-4225, Bangladesh
}

\begin{abstract}
Bats of the genus Pteropus $(P$.) under the class Mammalia are important ecologically as pollinators, but little is known about their basic physiology. For this, serum biochemical values of healthy wild captured frugivorus bats ( $P$. giganteus) were determined for providing baseline information and health care assessments in zoological setting. Ninety clinically healthy large frugivorous bats were captured from the wild and anesthetized for 2 hours following capture for blood collection from brachial vein. Serum glucose, total protein (TP), triglyceride (TG), cholesterol, alanine aminotransferase (ALT), aspartate aminotransferase (AST), alkaline phosphatase (ALP), creatinine phosphokinase (CPK), urea, uric acid, calcium and phosphorus were determined using biochemical analyzer. No major differences were observed in the serum biochemical values between male and female bats, juvenile and adults or fair and good health-state bats except significant variation in the AST $(\mathrm{p}<0.05)$, ALP $(\mathrm{p}<0.05)$ and CPK $(\mathrm{p}<0.05)$ between adult and juvenile bats, calcium $(\mathrm{p}<0.01)$ and phosphorus $(\mathrm{p}<0.01)$ between the good and fair health-state bats. The values from this study can be used to create reference intervals of serum biochemistry of bat found in Indian subcontinent, and they can make up the first comprehensive biochemical study for this highly endangered species.
\end{abstract}

Key words: Bat, biochemical, body condition, age, sex

\section{INTRODUCTION}

Different species of fruit bats are ecologically and commercially important as they serve as pollinators of various genera of plants (Crooks et al., 2003). Among various species, large frugivorus bat of genus Pteropus, Pteropus giganteus is the gigantic type of fruit bats in Indian sub-continent (Bates et. al., 1997). Serum biochemistry and hematology are valuable indicators that provide crucial information on animal's health and immune status while trying to understand the potential effects of infection with a specific pathogen (McLaughlin et al., 2007). Plasma biochemical analyses of wild-caught large frugivorous bats $(P$. giganteus) may be used to assess population health of bats and can serve as indicators of nutritional status, disease, trauma, and environmental changes, such as altered habitat quality (McLaughlin et al., 2007). Considering the above background, an extended trapping exercise was conducted in 2012 for the purpose of population census, demographic information (age and sex) and health assessments. This trapping exercise provided a valuable opportunity of collecting blood samples from clinically healthy bat population for serum biochemical analysis that could be used in future disease investigations.

\section{MATERIALS AND METHODS}

\section{Study area}

Ninety apparently healthy Pteropus giganteus were captured using mist-net at Cox's Bazar district in Bangladesh from a colony of approximately 1000 bats. This colony is situated in a public recreation area and open throughout the year.

\section{Sample collection}

The Pteropus giganteus $(\mathrm{N}=90)$ were captured over a period of seven nights in late October, 2012, with the use of an 18-m mist-net suspended between two 12-m bamboo masts. Captured bats were placed in cloth bags until processing. Sex, age and body condition score were recorded for each bat. The adult bats $(\mathrm{n}=53)$ weighed $563.5 \mathrm{~g}$ on average whereas juveniles $(\mathrm{n}=36)$ had the average weight of $444 \mathrm{~g}$. Among all the studied bats, male bats $(\mathrm{n}=52)$ weighed $505.5 \mathrm{~g}$ whereas female bats $(\mathrm{n}=38)$ weighed $530.6 \mathrm{~g}$. Moreover, fair-health bats $(n=73)$ weighed $493.7 \mathrm{~g}$ and the bats with good health $(n=17)$ had the body weight of 612.1 g.

*Corresponding e-mail address: mbhossaincvasu@yahoo.com Copyright (c) 2013 Bangladesh Society for Veterinary Medicine 


\section{B. Hossain and others}

Bats were classified as either juvenile or adult based on secondary sexual characteristics: presence of penile barbs in case of males and elongated and white-tipped teats indicating lactation in the case of females. Body condition score (BCS) was classified as either fair or good, based on relative pectoral muscle mass and prominence of sternum. A fair BCS reflected a prominent sternum and minimal muscle mass where as a good BCS reflected minimally prominent sternum and substantial pectoral muscle mass. Pregnancy was determined by abdominal palpation and lactation status by excretion of milk from the teats. All bats were marked with commercially available nail polish on the hind limb claws to prevent repeated sampling of the same individual. Bats were manually anesthetized using gaseous anesthetic fluthane. $2 \mathrm{ml}$ of blood was drawn from the brachial vein at the distal humerus with the use of a 3-ml syringe and transferred to a vacutainer for smooth coagulation. Serum samples were obtained by centrifugation of clotted blood and serum was kept in $1.5 \mathrm{ml}$ plastic Eppendorf tubes (Thermo Fisher Scientific International, Inc.) and stored at $-20^{\circ} \mathrm{C}$ until processed. Vein puncture sites on captured bats were evaluated for injury. Animals were released at the trap site $2-4 \mathrm{~h}$ post capture.

\section{Sample processing}

Serum samples were allowed to thaw at ambient temperature and were processed within 1 hour of thawing. Selected plasma biochemistry values $(n=90)$ were analyzed with biochemical analyzer (Humalyzer $3000^{\circledR}$ Germany) in biochemistry laboratory of Chittagong Veterinary and Animal Sciences University, according to the manufacturer's guidelines. Total protein (TP), triglyceride (TG), glucose, urea, uric acid, cholesterol, alanine aminotransferase (ALT), aspartate aminotransferase (AST), alkaline phosphatase (ALP) and creatinine phosphokinase (CPK) were analyzed. Because of limited serum volume of some samples, they were diluted 50:50 with $0.9 \%$ saline and machine readings were doubled according to the manufacturer's product information.

\section{Statistical analysis}

Data found on analysis of serum samples were first stored into the MS Excel-2007, cleaned, sorted and exported to statistical software STATA-11 for descriptive statistical analysis. Results were expressed as Mean \pm Standard Error of Mean (SEM), 95\% Confidence Interval (CI). P was considered significant when $\mathrm{p}<0.05$.

\section{RESULTS AND DISCUSSION}

Ninety blood samples were obtained from frugivorous bats which were found apparently healthy on the basis of clinical examination. Hematoma formation occasionally occurred during blood collection. All bats were observed flying to the roost from the release site. Serum biochemistry is reported in Table 1, 2 and 3. Table 1 shows serum biochemistry values (mean \pm SEM) for wild-caught large frugivorous bats (Pteropus giganteus $)$ according to sex category. TP $(72.1 \mathrm{~g} / \mathrm{L})$, TG $(98.1 \mathrm{~g} / \mathrm{L})$, glucose $(151.9 \mathrm{mmol} / \mathrm{L})$, AST $(108.4$ $\mu \mathrm{kat} / \mathrm{L})$, and ALP $(992 \mu \mathrm{kat} / \mathrm{L})$ levels appear higher in female than male but are not significant. By contrast, urea $(65.2 \mathrm{mmol} / \mathrm{L})$, uric acid $(2.9 \mathrm{mmol} / \mathrm{L})$, cholesterol $(63.6 \mathrm{mmol} / \mathrm{L})$ and $\mathrm{CPK}(57.4 \mu \mathrm{kat} / \mathrm{L})$ values are found high in male as compared to the female.

Significant $(p<0.05)$ variation in cholesterol level is found between male and female. There is no significant difference between the mean uric acid value of male and female $(p>0.05)$. The mean values of both calcium and phosphorus in both sexes of bats are found within normal range; for male, the observed values of calcium and phosphorus are $13.4 \mathrm{mg} / \mathrm{dl}$ and $10.9 \mathrm{mg} / \mathrm{dl}$ respectably and for female, these values are $13.2 \mathrm{mg} / \mathrm{dl}$ and $11.3 \mathrm{mg} / \mathrm{dl}$ respectably. However, these values do not differ significantly.

The mean values of glucose $(149.5 \mathrm{mmol} / \mathrm{L}), \mathrm{TP}(71.7 \mathrm{~g} / \mathrm{L})$, cholesterol $(61 \mathrm{mmol} / \mathrm{L})$, ALT $(17.7 \mu \mathrm{kat} / \mathrm{L})$, AST $(105.5 \mu \mathrm{kat} / \mathrm{L})$, CPK $(70.5 \mu \mathrm{kat} / \mathrm{L})$ and urea $(70.9 \mathrm{mmol} / \mathrm{L})$ are found to be higher in adult bats and mean values of triglyceride $(94.9 \mathrm{~g} / \mathrm{L})$, ALP $(1229.4 \mu \mathrm{kat} / \mathrm{L})$, calcium $(13.6 \mathrm{mg} / \mathrm{dl})$, phosphorus $(13.1 \mathrm{mg} / \mathrm{dl})$ and uric acid $(2.7 \mathrm{mmol} / \mathrm{L})$ have been found higher in juvenile bats (Table-2). Significant differences between adult and juvenile bats are observed for AST $(\mathrm{p}<0.05)$, ALP $(\mathrm{p}<0.01)$ and CPK $(\mathrm{p}<0.05)$. Though the mean values for calcium between juvenile and adult bats do not differed significantly, yet phosphorus levels vary significantly $(\mathrm{p}<0.05)$. 
Table 1. Selected macromolecules and trace elements found in serum of Indian flying fox (Pteropus giganteus) based on sex

\begin{tabular}{|c|c|c|c|c|c|c|c|}
\hline \multirow{3}{*}{$\begin{array}{c}\text { Biochemical } \\
\text { Parameters }\end{array}$} & \multicolumn{7}{|c|}{ Category } \\
\hline & \multicolumn{3}{|c|}{ Male } & \multicolumn{3}{|c|}{ Female } & \multirow[t]{2}{*}{$P$ value } \\
\hline & $\mathrm{n}$ & Mean \pm SEM & $95 \% \mathrm{CI}$ & $\mathrm{n}$ & Mean \pm SEM & $95 \% \mathrm{CI}$ & \\
\hline Glucose (mmol/L) & 43 & $129.6 \pm 17.2$ & $94.9-164.2$ & 27 & $151.9 \pm 23.2$ & 104.1-199.7 & 0.443 \\
\hline Total Protein $(\mathrm{TP})(\mathrm{g} / \mathrm{L})$ & 36 & $69.4 \pm 3.7$ & $61.8-76.9$ & 21 & $72.1 \pm 2.8$ & $66.2-78.0$ & 0.564 \\
\hline Albumin (g/L) & 44 & $31.3 \pm 5.0$ & $21.2-41.5$ & 29 & $35.3 \pm 5.4$ & $24.1-46.4$ & 0.597 \\
\hline $\mathrm{TG}(\mathrm{g} / \mathrm{L})$ & 46 & $88.3 \pm 4.5$ & $79.3-97.2$ & 30 & $98.1 \pm 5.3$ & $87.4-108.9$ & 0.157 \\
\hline Cholesterol (mmol/L) & 41 & $63.6 \pm 3.6$ & $56.4-70.8$ & 24 & $48.0 \pm 3.0$ & $41.7-54.2$ & 0.001 \\
\hline $\operatorname{ALT}(\mu \mathrm{kat} / \mathrm{L})$ & 25 & $17.1 \pm 1.3$ & $14.3-19.8$ & 14 & $17.0 \pm 2.6$ & $11.4-22.7$ & 0.993 \\
\hline AST $(\mu \mathrm{kat} / \mathrm{L})$ & 22 & $75.0 \pm 8.9$ & $56.2-93.5$ & 22 & $108.4 \pm 16.5$ & $74.1-142.7$ & 0.083 \\
\hline ALP $(\mu \mathrm{kat} / \mathrm{L})$ & 15 & $875 \pm 113.5$ & $631-1118.2$ & 12 & $992 \pm 110.9$ & $747.8-1236.1$ & 0.467 \\
\hline CPK $(\mu \mathrm{kat} / \mathrm{L})$ & 19 & $57.4 \pm 20.2$ & $15-100$ & 15 & $41.6 \pm 10$ & $20.2-63$ & 0.489 \\
\hline Calcium (mg/dl) & 37 & $13.4 \pm 0.9$ & $11.6-15.3$ & 23 & $13.2 \pm 1.1$ & $11.0-15.5$ & 0.891 \\
\hline Phosphorus (mg/dl) & 35 & $10.9 \pm 1.1$ & $8.5-13.2$ & 25 & $11.3 \pm 1.3$ & $8.6-14.0$ & 0.808 \\
\hline Urea (mmol/L) & 19 & $65.2 \pm 9.8$ & $44.7-85.7$ & 16 & $54.1 \pm 9.0$ & $35.0-73.2$ & 0.408 \\
\hline Uric acid $(\mathrm{mmol} / \mathrm{L})$ & 23 & $2.9 \pm 0.5$ & $1.9-3.8$ & 12 & $2.2 \pm 0.4$ & $1.3-3.1$ & 0.261 \\
\hline
\end{tabular}

Table 2. Selected macromolecules and trace elements in serum of Indian flying fox (Pteropus giganteus) based on age

\begin{tabular}{|c|c|c|c|c|c|c|c|}
\hline \multirow[t]{3}{*}{ Biochemical } & \multicolumn{7}{|c|}{ Category } \\
\hline & \multicolumn{3}{|c|}{ Juvenile } & \multicolumn{3}{|c|}{ Adult } & \multirow{2}{*}{$\mathrm{P}$ value } \\
\hline & $\mathrm{n}$ & Mean \pm SEM & $95 \% \mathrm{CI}$ & $\mathrm{n}$ & Mean \pm SEM & $95 \% \mathrm{CI}$ & \\
\hline Glucose $(\mathrm{mmol} / \mathrm{L})$ & 28 & $121.3 \pm 20.3$ & $79.6-162.9$ & 41 & $149.5 \pm 19.1$ & $111.0-188.0$ & 0.313 \\
\hline Total proteins $(\mathrm{g} / \mathrm{L})$ & 24 & $66.1 \pm 4.6$ & $56.7-75.6$ & 32 & $71.7 \pm 2.3$ & $67.0-76.4$ & 0.284 \\
\hline Albumin & 30 & $33.7 \pm 6.3$ & $20.7-46.7$ & 42 & $30.9 \pm 4.4$ & 21.9-39.9 & 0.715 \\
\hline Triglyceride (g/L) & 31 & $94.9 \pm 5.5$ & $83.7-106.1$ & 44 & $89.7 \pm 4.5$ & $80.7-98.8$ & 0.467 \\
\hline Cholesterol (mmol/L) & 27 & $52.2 \pm 3.2$ & $45.6-58.9$ & 37 & $61.0 \pm 3.9$ & $53.2-68.9$ & 0.086 \\
\hline $\operatorname{ALT}(\mu \mathrm{kat} / \mathrm{L})$ & 14 & $16.0 \pm 1.8$ & $12.1-19.9$ & 25 & $17.7 \pm 1.7$ & $14.2-21.1$ & 0.500 \\
\hline $\operatorname{AST}(\mu \mathrm{kat} / \mathrm{L})$ & 16 & $70.4 \pm 8.89$ & $51.5-89.4$ & 27 & $105.5 \pm 14.24$ & $76.2-134.8$ & 0.043 \\
\hline ALP $(\mu \mathrm{kat} / \mathrm{L})$ & 9 & $1229 \pm 94.1$ & $1012-1446.4$ & 18 & $775.5 \pm 91.3$ & $582.8-968.1$ & 0.002 \\
\hline CPK $(\mu \mathrm{kat} / \mathrm{L})$ & 14 & $24.8 \pm 3.5$ & $17.2-32.3$ & 19 & $70.5 \pm 20.5$ & $27.5-113.5$ & 0.040 \\
\hline Calcium (mg/dl) & 25 & $13.6 \pm 0.8$ & $11.8-15.3$ & 34 & $13.4 \pm 1.1$ & $11.2-15.5$ & 0.889 \\
\hline Phosphorus (mg/dl) & 25 & $13.1 \pm 1.4$ & $10.1-16.1$ & 34 & $9.5 \pm 1.0$ & $7.5-11.5$ & 0.047 \\
\hline Urea $(\mathrm{mmol} / \mathrm{L})$ & 14 & $47.3 \pm 12.4$ & $20.4-74.1$ & 20 & $70.9 \pm 7.1$ & $56.2-85.7$ & 0.112 \\
\hline Uric acid $(\mathrm{mmol} / \mathrm{L})$ & 21 & $2.7 \pm 0.4$ & $1.8-3.6$ & 13 & $2.3 \pm 0.5$ & $1.3-3.4$ & 0.582 \\
\hline
\end{tabular}




\section{B. Hossain and others}

Table 3. Selected macromolecules and trace elements in serum of Indian flying fox (Pteropus giganteus) based on body condition score (BCS)

\begin{tabular}{|lccccccc|}
\hline Parameters & \multicolumn{7}{c}{ Category } \\
\hline & $\mathrm{n}$ & Mean \pm SEM & $95 \% \mathrm{CI}$ & $\mathrm{n}$ & Mean \pm SEM & $95 \%$ CI & P value \\
\hline Glucose $(\mathrm{mmol} / \mathrm{L})$ & 57 & $140 \pm 16.7$ & $106.4-173.5$ & 13 & $130.3 \pm 12.3$ & $103.4-157.2$ & 0.643 \\
Total proteins $(\mathrm{g} / \mathrm{L})$ & 45 & $67.6 \pm 3.0$ & $61.5-73.8$ & 12 & $80.7 \pm 2.6$ & $74.9-86.4$ & 0.002 \\
Albumin $(\mathrm{g} / \mathrm{L})$ & 60 & $29.6 \pm 4.2$ & $21.2-38.0$ & 13 & $48.1 \pm 6.2$ & $34.5-61.6$ & 0.021 \\
Triglyceride $(\mathrm{g} / \mathrm{L})$ & 64 & $92.1 \pm 3.9$ & $84.3-100.0$ & 12 & $92.3 \pm 5.9$ & $79.3-105.2$ & 0.985 \\
Cholesterol $(\mathrm{mmol} / \mathrm{L})$ & 53 & $59.5 \pm 3.0$ & $53.4-65.6$ & 12 & $50.3 \pm 5.0$ & $39.3-61.4$ & 0.133 \\
ALT $(\mu \mathrm{kat} / \mathrm{L})$ & 30 & $15.9 \pm 1.3$ & $13.2-18.5$ & 9 & $21.2 \pm 2.9$ & $14.5-27.9$ & 0.123 \\
AST $(\mu \mathrm{kat} / \mathrm{L})$ & 33 & $88.6 \pm 10.2$ & $67.9-109.3$ & 11 & $100.7 \pm 24.3$ & $46.6-154.8$ & 0.654 \\
ALP $(\mu \mathrm{kat} / \mathrm{L})$ & 16 & $1071.4 \pm 77.9$ & $905.3-1237.5$ & 11 & $716.3 \pm 139.6$ & $405.2-1027.5$ & 0.041 \\
CPK $(\mu \mathrm{kat} / \mathrm{L})$ & 24 & $40.4 \pm 12.2$ & $15.7-65.7$ & 10 & $74.6 \pm 28.3$ & $10.6-138.6$ & 0.288 \\
Calcium $(\mathrm{mg} / \mathrm{dl})$ & 48 & $14.2 \pm 0.8$ & $12.6-15.9$ & 12 & $9.9 \pm 0.6$ & $8.6-11.1$ & 0.0001 \\
Phosphorus $(\mathrm{mg} / \mathrm{dl})$ & 48 & $12.1 \pm 0.9$ & $10.1-14.1$ & 12 & $6.9 \pm 0.8$ & $5.1-8.8$ & 0.0003 \\
Urea $(\mathrm{mmol} / \mathrm{L})$ & 24 & $54.4 \pm 8.4$ & $37.0-71.8$ & 11 & $72.7 \pm 10.2$ & $49.9-95.5$ & 0.182 \\
Uric acid(mmol/L) & 32 & $2.5 \pm 0.3$ & $1.8-3.2$ & 3 & $3.8 \pm 1.7$ & $3.68-11.2$ & 0.553 \\
\hline
\end{tabular}

While considering BCS, total protein $(80.7 \mathrm{~g} / \mathrm{L})$, triglyceride $(92.3 \mathrm{~g} / \mathrm{L})$, glucose $(130.3 \mathrm{mmol} / \mathrm{L})$, urea $(72.7 \mathrm{mmol} / \mathrm{L})$, uric acid $(3.8 \mathrm{mmol} / \mathrm{L})$ and ALT $(21.2 \mu \mathrm{kat} / \mathrm{L})$ have been found higher in bats which were in good health but opposite result is observed for cholesterol (Table 3). A significant difference of total protein $(\mathrm{p}<0.01)$ is revealed between healthy (good) and weak (fair) bats. In good state healthy bats, both calcium and phosphorus are recorded lower than fairly healthy bats. The level of calcium $(p<0.01)$ and phosphorus $(p<0.01)$ between both good and fair health state of bats differs significantly.

The large frugivorous bats (Pteropus giganteus) are a common and ecologically beneficial species in Indian subcontinent and the present study was conducted among 90 such wild-caught large frugivorous bats captured from a roost situated at Cox's Bazar in Bangladesh in order to assess their biochemical parameters such as glucose, TP, TG, Cholesterol, ALT, AST, ALP, CKP, urea, uric acid, calcium and phosphorus. Significant difference was observed in AST $(p<0.05)$, ALP $(p<0.05)$ and CPK $(p<0.05)$ between adult and juvenile bats, calcium $(\mathrm{p}<0.01)$ and phosphorus $(\mathrm{p}<0.01)$ between the good and fair health state bats. The average glucose level has been estimated $138.2 \mathrm{mg} / \mathrm{dl}$ which is slightly higher than the earlier studies by Heard et al. (2006) who reported $133.2 \mathrm{mg} / \mathrm{dl}$ serum glucose in Indian flying fox (Pteropus giganteus) and it may be attributable to minimum time from sample collection to centrifugation (Heard et al., 2006). Total protein for wild-caught large frugivorous bat (Pteropus giganteus) in the present study coincides with the findings of earlier study of Heard et al. (2006) who found $70 \mathrm{gm} / \mathrm{L}$ in the same species. Total levels of cholesterol and triglyceride in the present study are almost $58 \mathrm{mg} / \mathrm{dl}$ and $92 \mathrm{mg} / \mathrm{dl}$ respectively but these values do not agree with previous findings by Heard et al. (2006) who reported 2.31 times and 7.5 times higher cholesterol and triglyceride, consecutively. The lower cholesterol concentration might be due to the relatively low-protein diet of frugivorous bats. The elevated levels of calcium $(13.4 \mathrm{mg} / \mathrm{dl})$, phosphorus $(11.0 \mathrm{mg} / \mathrm{dl})$ and ALP $(926.76 \mu \mathrm{kat} / \mathrm{L})$ presented in this study are higher than the previous study undertaken by Heard et al. (2006) who reported $9.36 \mathrm{mg} / \mathrm{dl}$ of calcium, $4.43 \mathrm{mg} / \mathrm{dl}$ of phosphorus and $615 \mu \mathrm{kal} / \mathrm{L}$ of ALP in their samples and this might be due to greater osteogenic activity in growing animals (Kaneko, 1989). Both AST and ALT have been found higher in the studied bats and this does not correspond to the earlier finding of Heard and Whittier (1997) which could be due to low enzymatic degradation. Alkaline phosphatase is found high in the present study as compared to earlier study (Heard et al., 2006). Total protein levels apparently varied in different categories (sex, age etc.) but only significant difference was observed between good and fair health state of bats $(\mathrm{p}<0.05)$ which is nearly similar with the finding of Heard et al. (2006) who reported $73 \mathrm{gm} / \mathrm{L}$ plasma total protein in Malaysian flying foxes (Pteropus vampyrus).

The findings of this study could be used to evaluate population health of bats, nutritional status, disease, trauma, and environmental changes, such as altered habitat quality etc. and may be used for future reference. 


\section{ACKNOWLEDGEMENTS}

We are grateful to the Bat Conservation International for financial support and the Group for Conservation and Research of Bat (GCRB) \& Eco Health Alliance for logistic support. We are also grateful to laboratory staffs of Physiology, Biochemistry and Pharmacology of Chittagong Veterinary and Animal Sciences University.

\section{REFERENCES}

1. Bates PJJ and Harrison DL (1997). Bats of the Indian Subcontinent. Harrison Zoological Museum Publication, Kent, England. pp. 13-15.

2. Crooks KR, Garcelon DK, Scott CA, Wilcox JT, Timm SF and Van Vuren DH (2003). Hematology and serum chemistry of the island spotted skunk on Santa Cruz Island. Journal of Wildlife Disease 39: 460 466.

3. Heard DJ, Ruiz MM and Harr KE (2006). Comparison of serum and plasma for determination of blood biochemical values in Malaysian flying foxes (Pteropus vampyrus). Journal of Zoo and Wildlife Medicine 37(3): 245-248.

4. Heard DJ and Whittier DA (1997). Hematologic and plasma biochemical reference values for three flying fox species (Pteropus sp.). Journal of Zoo Wildlife Medicine 28: 464-470.

5. Kaneko JJ (1989). Clinical Biochemistry of Domestic Animal. $4^{\text {th }}$ edn. Academic Press, Inc., San Diego, California.

6. McLaughlin AB, Epstein JP, Prakash V, Smith CS, Daszak P, Field HE and Cunningham AA (2007). Plasma biochemistry and hematologic values for wild-caught flying foxes (Pteropus giganteus) in India. Journal of Zoo and Wildlife Medicine 38(3): 446-452. 